DOI $10.31651 / 2524-2660-2019-4-168-172$

ORCID 0000-0002-5930-8558

\title{
ПАКУШИНА Аюдмиха Зиновіївна,
}

кандидатка педагогічних наук, старша викладачка кафедри соціальної роботи та соціальної педагогіки,

Черкаський національний університет імені Богдана Хмельницького e-mail: pakushyn2007@gmail.com

ORCID 0000-0002-2267-3770

\section{ХАБУРСЬКА Оксана Володимирівна,}

магістрантка кафедри соціальної роботи і соціальної педагогіки,

Черкаський національний університет імені Богдана Хмельницького

e-mail:khaburska@i.ua

УДК 351.764.013.42(045)

\section{ОСОБАИВОСТІ СОЦІААЬНОЇ РОБОТИ ІЗ ПРАЦІВНИКАМИ КОМЕРЦІЙНОГО СЕКСУ В УКРАЇНI}

Представлено особливості соиіальної роботи із представниками комериійного сексу в Украйні.

Визначено, шо в Україні вирішення проблем праиівників комериійного сексу здійснюеться за аболіиіоністсъкою моделлю, відповідно до якої соиіальну допомогу секс-праиівники можуть отримувати лише завдяки діяльності громадсъких організаиій.

Розглянуто можливості надання відповідої допомоги праиівникам комериійного сексу на прикладі двох украӥнських громадських організаüiŭ.

Ключові слова: комериійний секс; проституиіл; праиівники комериійного сексу; соиіальна робота із праиівниками секс-бізнесу; аутрічробота; аутріч-марирут.

Постановка пробцеми. Секс-індустрія або секс-бізнес явцяє собою широко розповсюджений у всіх країнах світу феномен, породжений гмобальною економічною нерівністю й гендерною дискримінацією. Мюди, які вступають у ділові стосунки купівліпродажу або обміну сексуальних послуг за винагороду, традиційно називаються проститутками чи проститутами $[1$, с. 5]. Проте, згідно з рекомендаціями Об'єднаної програми ООН з ВІА/СНІДУ (ЮНЕЙДС) щодо вживання понять від 2011 р., нині їх прийнято називати "секс-працівниками", "працівниками комерційного сексу" або "особами, які надають сексуальні послуги за винагороду" [2]. Крім того Гцобальний фонд боротьби з ВІ $\Lambda$-інфекцією та СНІДом вже близько двадцяти років фінансує проведення в Україні різних проектів, спрямо-

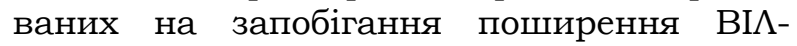
інфекції в Україні. Однією із умов фінансування таких проектів $€$ формування то- мерантного ставцення населення до уразмивих до ВІ $/$ СНІД-груп. У зв'язку із цим рекомендовано замість терміну "повія" використання поняття "працівниця сексбізнесу", як таке, що демонструє толерантне ставлення й зменшує стигматизацію цієї уразмивої категорії.

В Україні надання секс-послуг є адміністративним порушенням і соціум неоднозначно ставиться до такої діяльності. У вересні 2015 року до Верховної Ради України надійшов законопроект про мегалізацію проституції, який не був прийнятим. Тому це явище досі залишається невизнаним у суспільстві [3, с.150].

Проте міжнародна громадськість $є$ надзвичайно стурбованою масштабами проституції, експлуатації їі третіми особами, а також темпами поширення ВІ $/ \mathrm{CHIДу}$ (хвороби, яка напряму пов'язана із сексбізнесом). Це змушує уряди, міжнародні й неурядові організації визнавати необхідність у сприянні охороні здоров'я секспрацівників й визнавати, що такий вид діяльності існує й має свої ризики й небезпеки [4, с. 10]. А тому секс-працівники мають певні, закономірні соціальні проблеми, які, як зауважує А. Протопопов, кожна держава вирішує комплексно на законодавчому й адміністративному рівнях, а також через соціальну роботу [1, c. 119]. Україна не $є$ виключенням і теж змушена вирішувати такі проблеми своїх громадян аналогічно, зважаючи на досвід інших країн, та використовучи при цьому як законодавчий і адміністративний ресурси, так і ресурс соціальної роботи. Проте, 
варто зауважити, що нині соціальна робота в Україні є відносно новим видом професійної діяльності, який активно розвивається й намагається розширювати діапазон своїх повноважень. Тому, можна впевнено стверджувати, що проблеми та перспективи розвитку соціальної роботи із працівниками секс-бізнесу в Україні вивчені недостатньо і потребують відповідних наукових розвідок.

Анаміз останніх досліджень і пубиікацій. Вивченням проституції як соціального явища займамися такі радянські та російські вчені, як Ю. Антонян, В. Афанас'єв, Б. Цуккер, С. Голод, Я. Гімінський, А. Дьяченко, I. Кон, А. Сабінін, В. Тарновський, Х. Чарихов. Серед українських досмідників проституції та комерційного сексу слід згадати таких вчених, як О. Балакірєва, Т. Бондар, Ю. Галустян, I. Барков, ^. Бондаренко, П. Курмаєв, О. Миронець, I. Капустяк, О. Надьон, А. Протопопов, Н. Савельєва, О. Радутний, Ю. Саранков, К. Снісаренко, А. Шиделко та інші.

Їх роботи переважно присвячені медико-соціально-психологічним та юридичним особливостям і причинам цього феномену, можливостям його декриміналізації в Україні, взаємозв'язку із ВІ $\Lambda$-інфекцією. Ми погоджуємося із думкою більшості науковців, що викорінити це явище у суспільстві практично неможливо, а тому варто практикувати методи регламентації, які можуть забезпечити контроць суспільства за проституцією як соціальним явищем і за тими особами, які ним займаються [5, с. 97]. Тому метою статті є розкриття особливостей соціальної роботи із працівниками комерційного сексу, які існують на даний момент розвитку нашої держави.

Виклад основного матеріалу дослідження. Залежно від законодавств та відповідно до ставлення суспільств різних країн світу у цілому до явища сексіндустрії, сучасні дослідники виділяють три основні моделі регулювання проституції. Перша - декримінаційна, яка передбачає мегальність секс-індустрії у державі (характерна для Нідерландів, Німеччини, Австрамії, Греції, Швейцарії, Ізраї^ю, Туреччини, Перу, Еквадора). Друга - модемь обмеженої мегалізації. Спостерігається у Великій Британії, Бельгії, Канаді, Індії, Угорщині - де проституція не вважається зцочином, але за законом караються дії, спрямовані на втягування жінок до проституції та отримання за це прибутку. Третя - це аболіціоністська модемь (запроваджена у більшості країн світу серед яких і Україна), яка визнає проституцію аморальною діяльністю за яку кримінального покарання не передбачено, але яка має бути повністю знищена у країні і тому будь-яка "експлуатація проституції іншої особи" передбачає кримінамьну відповідальність. Тобто кримінальними вважаються усі дії, пов'язані із втягуванням у цю діяльність. Саме такі заборони призводять до того, що проституція в Україні змушена переховуватися, і можливості дмя проведення широкомасштабних медичних і соціальних інтервенцій необхідних для забезпечення потреб працівників секс-бізнесу набагато вужчі, ніж у країнах де така діяльність декриміналізована або хоча б частково мегамізована [6, с. 117-118].

Отримувачами послуг соціальних працівників, згідно із чинним українським законодавством [7], можуть бути особи/сім’і, які належать до вразцивих груп населення та/або перебувають у складних життєвих обставинах. Тому спробуємо визначити ознаки вразцивості, що притаманні працівницям секс-бізнесу в Україні.

Стрижневою особливістю вразцивості таких $ю$ юей $є$ їх криміналізація, яка призводить до: насицьства; змовживань з боку поліції; травмувань та навіть смертності, пов'язаної із роботою; низької самооцінки та психологічних розцадів; втрати родини та друзів; високого рівня стигми та дискримінації з боку оточуючих [1, с. 49].

Також варто відзначити наявність серйозних ризиків для фізичного, психологічного й соціального здоров'я секспрацівників, які також є ознаками вразци-

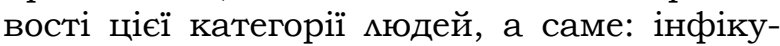
вання ВІА та інфекціями, що передаються статевим шляхом, фізичні травми, стреси, вживання наркотиків та алкоголю, небажана вагітність. [8, с. 44].

Дослідник О.В. Надьон зауважує, що сексуальний бізнес дає надзвичайно високий рівень прибутків і посідає друге місце після торгівлі наркотиками, випереджаючи за прибутковістю торгівлю зброєю та інші види нелегальної та мегальної комерційної діяльності. Крім того, поміж секс-жінок існує жорстка конкуренція, поширені випадки насимьства, що зумовлюють страх i заляканість його учасників. Тому сексбізнес у багатьох країнах залишається тіньовим і практично неможливо його викорінити у державі [5, с. 97].

Відповідно дослідження особливостей соціальної роботи із працівниками комерційного сексу також $є$ непростим завданням, яке ми спробували здійснити протягом 2018-2019 років у межах вимог написання та захисту магістерської роботи студентки спеціальності 231 "Соціальна робота" Черкаського національного університету імені Богдана Хмельницького. 
Із цією метою спочатку ми ознайомимися із діяльністю "Благодійної організації

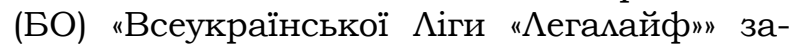
вдяки Інтернет-сайту $\Lambda$ іги, який широко висвітАює інформацію про усі свої справи. Таким чином ми з'ясували, що організація намагається здійснювати та підтримувати благодійну діяльність, спрямовану на: депеналізацію секс-роботи в Україні й відповідне покращення якості життя секспрацівників України; сприяти формуванню толерантного ставлення до секспрацівників з боку суспільства й покращення ситуації стосовно дотримання прав

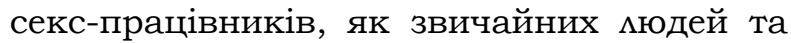
громадян України; протидію залучення до секс-роботи неповнолітніх, а також профімактику поширення ВІ $\Lambda$ СНІДу та інших соціально небезпечних хвороб серед секспрацівників [9].

У ході вивчення змісту роботи організації, з'ясовано, що протягом 2019 року пос-

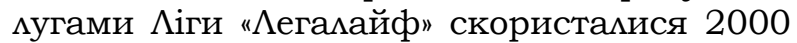
осіб, із яких переважна більшість жінки

комерційного сексу, які змогли отримати юридичну, медичну підтримку та допомогу спрямовану на поступове повернення до соціуму. Отже, організація надає такі посмуги, як:

- забезпечення проведення попередньої співбесіди за участю спеціалістапсихолога (за потребою);

- соціальний супровід за методом кейсменеджменту;

- медико-профілактичні (перша домедична допомога; організація консультації мікаря; направлення у заклади охорони здоров'я міста; профікактичні заходи);

- соціально-педагогічні;

- послуги юридичного характеру (сприяння в оформленні та відновценні документів, консультації щодо чинного законодавства);

- сприяння у працевлаштуванні.

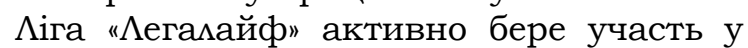
різних програмах і проектах приклади яких ми відобразили у табл. 1.

таблиия 1

\begin{tabular}{|c|c|}
\hline $\begin{array}{c}\text { Назва програми/партнер } \\
\text { підтримки }\end{array}$ & Завдання/цілі проекту \\
\hline $\begin{array}{c}\text { «Соціальна мобілізація, поси- } \\
\text { мення зв'язків, взаємодія та } \\
\text { координація" } \\
\text { (3 } 2017 \text { року) }\end{array}$ & 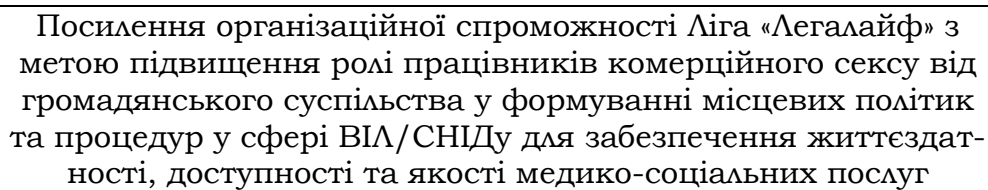 \\
\hline $\begin{array}{c}\text { «Партнерство заради натхнен- } \\
\text { ня, трансформації та } \\
\text { об’єднання відповіді } \\
\text { на ВІ } \Lambda \text { (РІТСН в Україні)» } \\
(2017) \\
\end{array}$ & $\begin{array}{c}\text { Адвокація жінок комерційного сексу та посилення адвока- } \\
\text { ційного потенціалу спільноти }\end{array}$ \\
\hline 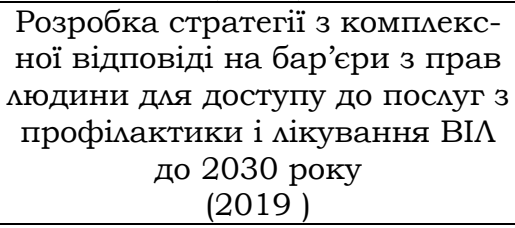 & $\begin{array}{l}\text { Передбачає підготовку медичних працівників з питань прав } \\
\text { мюдини та етики, пов'язаних із ВІА; підвищення обізнаності } \\
\text { законодавців і працівників правоохоронних органів; програ- } \\
\text { ми із забезпечення правової грамотності ("Знай свої права") }\end{array}$ \\
\hline
\end{tabular}

Проаналізувавши досвід організації, можна виділити кілька видів робіт, які $\epsilon$ найбільш дієвими в роботі 3 жінками комерційного сексу, а саме: аутрічробота, консультування, соціальний супровід, адвокація та матеріальна підтримка.

Також ми спробували з'ясувати особливості роботи Тернопільської міської громадської організації "Центр духовної та психологічної підтримки "Джерела"" (ГО "Джерела") завдяки виробничій фаховій практиці у процесі якої наша студентка мала змогу безпосередньо вивчати особливості роботи із жінками комерційного сексу шляхом спостережень, бесідами із фахівцями й представницями секс-бізнесу, ознайомленням із документацією та контентом Інтернет-сайту організації,.

Початок діяльності ГО "Джерела" відбувся у 2003 завдяки роботі ініціативної гру- пи, яка у 2004 році здійснила офіційну реєстрацію організації. Аналіз документації та інтернет-сайту ГО "Джерела", дав змогу визначити, що метою діяльності організації є:

- ведення просвітницької роботи серед громадян щодо профікактики розповсюдження ВI $\Lambda$-інфекції, а також серед чиенів сімей узалежнених та надання їм необхідної соціальної допомоги;

- заснування клубів та центрів психомогічної та духовної взаємодопомоги та взаємопідтримки для узалежнених осіб та чиенів їх сімей;

- організація дозвіляя для членів сімей, в яких проживають узалежнені особи, в тому числі клубів за інтересами.

- надання інформаційної допомоги освітнім, виховним, Аікувальним і пенітен- 
ціарним установам та закладам у їх діяльності з профілактики узалежнень;

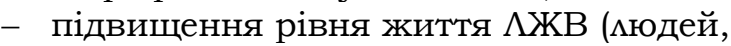

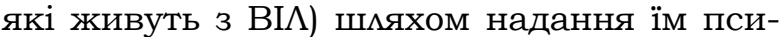
хомогічної, правової та соціальної допомоги [10].

У ході бесіди з працівниками ГО "Джерела" було з'ясовано, що цільовими групами організації є наркозалежні та члени їх родин, інфікованих, працівники комерційного сексу, ув'язнені, а також діти та молодь.

Тобто цільова група є більш широкою у

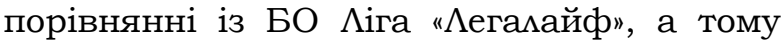
використовуються різні форми та методи роботи. Проте якщо говорити про роботу із жінками комерційного сексу, то одним із найбільш ефективних напрямів роботи із цією категорією клієнтів працівники ГО "Джерела" назвали вуличну або аутрічроботу, яка організована в межах програми профілактики ВІ $/$ СНІДу.
Із цією метою кожен соціальний працівник, який працює за програмою, має певний аутріч-маршрут, який включає місця найбільш частого перебування працівників секс-бізнесу. Під час проходження цього маршруту аутріч-працівники використовують різноманітні способи роботи $3 \mathrm{K \Lambda i \epsilon н-}$ тами серед яких: налагодження контакту із представниками цільових груп та інформування їх щодо актуальних для них проблем з метою вироблення навичок менш небезпечної поведінки в ризикованих ситуаціях; розповсюджування презервативів та шприців; консультування щодо можливостей конфіденційного тестування на ВI $\Lambda$ інфекцію, просвітницька робота та ін. У цілому процес аутріч-консультування від ГО "Джерела" здійснюється за певних етапів дмя яких рекомендовані показники відведеного часу на кожен із етапів у відсотковому співвідношенні (табц. 2).

\begin{tabular}{|l|c|}
\multicolumn{1}{|c}{ Етапи консультування } & Час у \% \\
\hline Етап 1. Встановлення контакту і довірчих взаємин з клієнтом & $35 \%$ \\
\hline Етап 2. Збір інформації & $15 \%$ \\
\hline Етап 3. Прояснення проблеми & $20 \%$ \\
\hline Етап 4. Рішення проблеми, включаючи інформування і мотивування & $25 \%$ \\
\hline Етап 5. Зворотній зв'язок і завершення консультування & $5 \%$ \\
\hline
\end{tabular}

Дия того щоб аутріч-консультування пройшло якомога успішніше, аутрічер має розповісти клієнту чи кАієнтці усе необхідне достатньо авторитетно, із використанням спеціальних термінів і водночас зрозуміло. Також в процесі аутрічконсультування важливо орієнтуватися в реакціях клієнта на спілкування і взаємодію 3 консультантом. Усе це потребує певної підготовки й досвіду, які здобуваються переважно шияхом самоосвіти та саморозвитку аутрічера.

У той же час ГО "Джерела", звертає увагу і на проблеми, що виникають у роботі вуличних працівників, а саме:

- низький рівень фрінансування програм вуличної роботи, що ускмаднює забезпечення вуличних соціальних працівників засобами (наприклад, телефонними картками, кавою для пригощання тощо), які сприяють налагодженню контакту;

- недостатність навчальних програм 3 підготовки вуличних соціальних працівників і волонтерів (проведення навчальних семінарів, курсів волонтерів, тренінгових програм);

- відсутність налагодженої взаємодії 3 представниками правоохоронних органів;

- нерозуміння сутності й важливості вуличної роботи з боку громадськості, яка інколи сприймає вуличну соціальну роботу як пропаганду наркотичних речовин або розпусти;
- небезпека маніпулювання вуличними працівниками з боку клієнтів: вони можуть чинити психологічний тиск 3 метою отримання необхідного їм інструментарію, а також підозрювати у співпраці з міліцією, що спричинює виникнення недовіри у кАієнта;

- високий ризик "вигорання" у вуличних соціальних працівників, пов'язаний як зі складністю роботи, так і з тим, що вулична робота для соціального працівника $\epsilon$ свого роду провокацією до зриву.

Працівники ГО "Джерела" відмітили, що ефективність використання вище зазначеного методу визначається змагодженістю дій фахівців, певною мірою розумінням 3 боку клієнтів та результатами, які досягаються у такій роботі з клієнтами.

Висновки i перспективи подапьших досліджень. 3 вищесказаного, можна зробити висновок, що соціальна робота із представниками секс-бізнесу в Україні обмежена діяльністю переважно громадських організацій. Розширити ці межі можна за умови мегалізації секс-бізнесу у державі, що поки залишається спірним питанням для суспільства. Тому дия покращення наявної ситуації напевно необхідні спеціально розроблені програми та методичні рекомендації дмя навчання аутрічерів, які можуть стати предметом подальших наукових розвідок та надбань. 


\section{Cписок бібціографічних посицань}

1. Проблемы секс-бизнеса в контексте общественного здравоохранения. Сост. Ю. Саранков. Киев: СПИД Фонд Восток-Запад, 2009. 128 с.

2. Ісаєва Н. Дотримання прав жінок, які належать до вразмивих груп населення. Київ, 2015 URL: http://afew.org.ua/wpcontent/uploads /2015/07/Prava-ginok-for-web.pdf

3. Радутний О. Е. Інформаційне забезпечення мегаАізації проституції та декриміналізації окремої пов'язаної з нею діяльності. Інформаиія і право. № 2(17). 2016. C. 147-157. URL: http://ippi.org.ua/sites/default/files/19_0.pdf

4. Как сдемать секс работу безопасной. Киев: МБФ «Международный Альянс по ВИЧ/СПИД в Украине", 2008. 120 c.

5. Надьон О. В. Проституція: соціальний аспект та кримінальний аналіз. Право $i$ безпека, 2005. № 4’4. С. 92-98

6. Протопопов А.О., Савельєва Н.М. Проституція як соціально-педагогічна проблема. За заг. ред. Н.М. Савельєвої. Полтава: Дивосвіт, 2009. 120 с.

7. Про соціальні послуги: Закон України від 17.01.2019. URL: https://zakon.rada.gov.ua/laws /show/2671-19

8. Гришина О.В., Хаустова О.О. Оцінка суїцидального ризику у жінок, які займаються проституцією. Соиіальна психіатрія. Архів психіатрії, 2014. №1(76), C. 43-46.

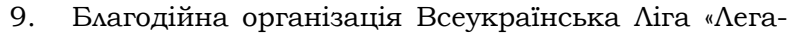
майср". URL: https://www.legalife.com.ua/about-us/\#

10. Тернопільська міська Громадська Організація "Центр духовної та психологічної підтримки "Джерела"». URL: https://dzherela.at.ua/

\section{References}

1. Problems of sex business in the context of public health (2009). In Yu. Sarankov (Compiler). Kyiv: East-West AIDS Fund (in Rus.).

2. Isaev, N. (2015). Compliance with the rights of women belonging to vulnerable groups. Retrieved 20/10/2019, from http://afew.org.ua/wp-content/uploads/2015 /07/Prava-ginok-for-web.pdf (in Ukr.).

3. Radutnyy, O.E. (2016). Informational support for the legalization of prostitution and the decriminalization of certain related activities. Information and law. 2(17), 147-157. Retrieved 20/10/2019, from http://ippi.org.ua/sites/default/files/19 0.pdf

4. How to make sex work safe (2008). Kyiv: ICF "International HIV / AIDS Alliance in Ukraine". $120 \mathrm{p}$.

5. Nadion, O.V. (2005). Prostitution: Social Aspect and Criminal Analysis. Law and security. 4’4, 92-98 (in Ukr.).

6. Protopopov, A.A., Savelyeva, N.M. (2009). Prostitution as a socio-pedagogical problem. In N.M Savelyeva (Ed.). Poltava: Wonderland (in Ukr.).

7. On social services: Law of Ukraine dated 17.01.2019. Retrieved 20/10/2019, from https:// zakon.rada.gov.ua/laws/show/2671-19 (in Ukr.).

8. Hryshyna, O.V., Khaustova, O.O. (2014). Assessment of suicidal risk in women involved in prostitution. Social psychiatry. Psychiatry Archive. №1(76), 43-46. (in Ukr.).

9. Charitable organization All-Ukrainian League "Legalife": Internet site of the organization. Retrieved 20/10/2019,

from https://www.legalife.com.ua/about-us/\# (in Ukr.).

10. Ternopil City Non-Governmental Organization "Sources" Center for Spiritual and Psychological Support: website of the organization. Retrieved 20/10/2019, from https://dzherela.at.ua/ (in Ukr.).

PAKUSHYNA Liudmila,

$\mathrm{PhD}$ in Pedagogy, Senior Teacher of Social Work and Social Pedagogy Department, Bohdan Khmelnitsky National University at Cherkasy

KHABURSKAYA Oksana,

Undergraduate of Social Work and Social Pedagogy Department, Bohdan Khmelnitsky National University at Cherkasy

\section{PECULIARITIES OF SOCIAL WORK WITH COMMERCIAL SEX WORKERS IN UKRAINE}

Summary. Introduction. The article reveals the peculiarities of social work with representatives of commercial sex in Ukraine. At present, this type of activity in Ukraine is not legal. But it exists and contributes to the spread of dangerous diseases and immorality among the population. Therefore, social preventative work among this category of population in Ukraine should be held, which will help to control the danger of this phenomenon.

Purpose. To reveal the features of modern social work with commercial sex workers in Ukraine

The method. The study used the following methods: analysis of NGO documentation, content analysis of NGO sites and conversations with social workers.

Results. It is determined that in Ukraine the problem of commercial sex workers is solved according to the abolitionist model. Such regulation of the problem by the state leads to the illegality of sex business in Ukraine. Therefore, neither state social service has the ability to work with such clients. But Ukrainian workers of sex industry can get social assistance through the work of NGOs that have support from the Global Fund to Fight HIV / AIDS. This fund has been financing various projects aimed at preventing the spread of HIV in our country for over twenty years.

Conclusion. Possibilities of providing assistance on the example of two Ukrainian public organizations are considered, namely: Charitable organization All-Ukrainian League "Legalife" and Ternopil public organization "Derela". Sex workers are found to be an extremely closed group of people. Therefore, outreach work is one of the most effective type of assistance to this category of population. The peculiarities and difficulties that are encountered in the work of street workers with this category of people are identified. Possibilities for improvement of social work with commercial sex workers are indicated by: 1) legalization of sex business in the state, 2) development of special programs and guidelines for outreach training.

Keywords: commercial sex; prostitution; commercial sex workers; social work with sex workers; outreach work; outreach route.

Одержано редакиією 14.11.2019 Прийнято до публікаиї̈ 07.12.2019 